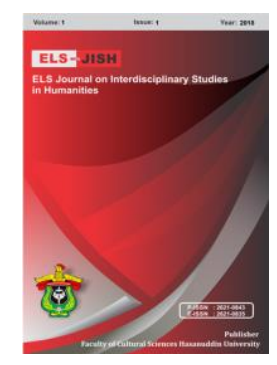

ELS-JISH

ELS Journal on Interdisciplinary Studies on Humanities

Volume 1 Issue 1, 2018

ISSN (print) : 2621-0843

ISSN (online) : 2621-0835

Homepage : http://journal.unhas.ac.id/index.php/jish

\title{
Politeness Strategy on Social Interaction Used by Munanese
}

\author{
Yetty ${ }^{1}$ \\ E-mail: etty metiuw@yahoo.com
}

\begin{abstract}
This study aims to investigate the differences of politeness strategy used by Munanese in their social interaction. The source of the data was verbal utterances of Munanese dialect Gu. This study used pragmatic study especially theory of politeness by Brown and Levinson, and supported by other theory particularly Yassi's theory. It also used descriptive qualitative method that is observation by recording and note taking. The result of the study showed the pattern politeness strategies used in Munanese Dialect Gu are; Hormat Non Kerabat; mixed, Hormat berkerabat; mixed and positive politeness (KP), Akrab Non Kerabat; mixed, Akrab Berkerabat; positive politeness (KP), Hierarki Non Kerabat; mixed (hierarchy), and (6) Hierarki Kerabat; mixed. The differences of the strategies maybe caused by several possible reasons including cultural differences, different age and social status when the people interact each other.
\end{abstract}

Keywords: politeness, social interaction, pragmatic

How to cite: Yetty. (2018). Politeness Strategy on Social Interaction Used by Munanese. ELS-Journal on Interdisciplinary Studies in Humanities, 1(1), 59-65.

\section{Introduction}

Language is a system that holds an important role in human life. It becomes a fundamental instrument of communication that allows people to communicate. They communicate through a language in order to convey their ideas, their needs, feeling, and expectations towards someone or something. Besides, the ways which people use language in their daily life are in order to have a connection or maintain their relationship.

The use of language in communication is a part of pragmatics study. According to Mey (2001:6) pragmatics as a study of the way human use their language in communication, bases itself on a study of those premises and determines how they affect, and effectualize, human language use. Moreover, according to Hence as cited in Mey (2001:6) pragmatics studies the use of language in human communication as determined by the condition of the society. In other words, pragmatics refers to the social language skill which people use in their interaction with others. It includes what they say, how they say, their body language and whether it is appropriate to the given situation or context.

One of important aspect of pragmatics competence is politeness. Yule (1996) stated that "politeness in an interaction can be defined as the means to show awareness of another person's face" (p. 60). The knowledge of politeness is important because politeness has an instrumental role in the social interaction.

${ }^{1}$ Faculty of Cultural Sciences, Hasanuddin University 
The theory of politeness was established by Brown and Levinson in 1987. They also introduced the notion of face which is most influential theory on politeness. It contains Face Threatening Acts (FTA) and politeness strategy. They state that everyone in the society has two kinds of face wants; negative face and positive face. Negative face is the basic claim to territories, personal preserves, right to non-distraction, i.e., face to freedom of action and freedom from imposition. Meanwhile, the positive face is the positive consistent self-image or personality claimed interacts. Moreover, according to Brown and Levinson every speaker and hearer should avoid threatening to face with considering potentially of face threatening act of a speech act due to some factors i.e Power (P), Distance (D) and R (Relationship) supported by cultural factors, social interaction and appropriate application of politeness strategy.

Scollon and Scollon (2012) have got three politeness systems; the deference politeness system, the solidarity politeness, and hierarchy politeness system. The distinction of the three systems is mainly based on the difference in the existence of power $(+P$ or $-P)$, and on the social distance between interlocutors $(+D$ or $-D)$ in which participants are considered to be equal or near equals but treat each other at a distance. Scollon and Scollon (2012) considers in a solidarity politeness system, the speaker may feel neither power difference (-P) nor social distance (-D) between themselves e.g friends. Their hierarchical politeness system may be widely recognized among companies, government and educational organizations, in which the speaker resorts to different politeness strategy; the 'higher' use involvement politeness strategies and the 'lower' use independence politeness strategies.

Yassi (2012) introduces six systems of politeness strategies on social interaction by adding one of systems that is Kinship (K); (1) Hormat Non Kerabat $(-P+D-K)$, (2) Hormat berkerabat $(-P+D-K)$, (3) Akrab Non Kerabat $(-P-D-K)$, (4) Akrab Berkerabat ($\mathrm{P}-\mathrm{D}+\mathrm{K})$, (5) Hierarki Non Kerabat $(+\mathrm{P}+\mathrm{D}-\mathrm{K})$, and $(6)$ Hierarki Kerabat $(+\mathrm{P}-\mathrm{D}+\mathrm{K})$. System number (1) until (4) is symmetry and system number (5) and (6) is asymmetry. Yassi's theory was introduced by his research of politeness system in Makassarese, and due to the cultural factor the theory is as the criticism of Brown and Levinson's theory.

In Yassi (2012) the politeness strategies used by Makassarrese based on the six strategies are Hormat Non Kerabat; mixed, Hormat berkerabat; positive politeness (KP), Akrab Non Kerabat; negative politeness (KN), Akrab Berkerabat; hierarki, Hierarki Non Kerabat; mixed (hierarki), and Hierarki Kerabat; mixed. Based on the explanation, this paper will be discussed about the politeness strategy of social interaction in Munanese by using Yassi's theory. The data will be obtained from Muna native speaker's utterances by recording and note taking. After collecting the data, it will be analyzed by using the Yassi's system of politeness strategies whether Muna people use positive politeness (KP), negative politeness $(\mathrm{KN})$ or Mixed. It will be seen whether there is the differences or the similarities of politeness strategies used by Munanese and Yassi's result according to the six systems of politeness.

\section{Research Method}

The researcher used descriptive qualitative method in conducting this research. Thus, this research described and elaborated the differences of politeness strategy used by Munanese in their social interaction. 


\subsection{Data Collection}

The data of this research was Muna language. In collecting Muna language data, the researcher used observation technique by investigating and observing Muna language used by Muna people. Besides, to strengthen the data, the researcher used in depth interview by asking some questions (supported by recording and note taking technique) concerning the using of politeness strategy used in their social interaction.

\subsection{Data Analysis}

In analyzing the data, the researcher used some technique. Firstly, the data from Muna language which gained from observation and in-depth interview transcribed. Then, it was reduced by selecting data which could representative others. The data based on Politeness strategy which divided by Brown and Levinson's supported by Yassis's presented. The presented data analyzed using pragmatic principle. The meaning of Muna language of politeness strategy concluded based on the information gained. After doing the analysis, finally the researcher made some conclusions which could reflect the main points of the analysis.

\section{Findings}

\subsection{Data Presentation}

\section{a. Hormat Non Kerabat (-P +D -K)}

\section{Data 1}

Here the interaction between two adult women who do not know each other or this is the first time they meet each other. The conversation took places on the ship. They were talking about their self and their family.
A : Femie anabuantoa? (How many children do you have?)

B : Popa (Four)

A : O popa. Pooto ga a idi popa dua. Semie moane idia (Oh four. It is same with me. I only have one son)

B : Ino'dia semie ho'bine, totolu moane.( I have one daughter and three sons)

A : Jadi we kolowa nando lambuntoa lae? (So, you have a house in Kolowa, don't you?)

B : Umbe. O hato lambuntoa we lombe we amai? (Yes. Then your house in Lombe where is the location?

A : We Watulea. (in Watulea)

STRATEGY: MIXED

\section{b. Hormat Berkerabat (-P +D +K)}

\section{Data 2}

This is the interaction between distance relatives. They are talking about the cashew. A is younger than $\mathrm{B}$. 
A : O no ko'bake toha dambuntoa lae? (the cashews ripe now, isn't it?)

B : Umbe. O dambuno futoku. Ane na ko'bake dambuno kamukulaa, mahingga da moni daeondofi anaia. ( Yes. It is my cashews. If the parents's cashews will have ripen the children can take it )

A : Umbe. (Yes)

STRATEGY: MIXED

\section{Data 3}

This is the interaction between distance relatives. They have same age.

A : Do foni we la ae te masigi inia? (With whom did you go to this mosque?)

B : Moisakua pa'a (I my self)

A : Me kakala mayu we lambua? (Did you go on foot from your house?)

B : Ae safi ne ojek. (I went by ojek)

STRATEGY: KP (CASUAL)

\section{c. Akrab Non Kerabat (-P -D -K)}

This is the interaction between two people. They are friends' relation.

\section{Data 4}

A : Alhamdulillah. Nando pahaso to? Lancar pahasontoa? (Are you selling? Are your selling running well?)

B : La ae? (Who?)

A : Intao'dia pa'a. Pahaso te lambu. (You. Sell at house)

$B$ : Umbe. (Yes)

STRATEGY: MIXED

\section{d. Akrab Berkerabat (-P -D +K)}

This is the interaction between two siblings. $A$ is a older sister and $B$ is younger sister.

\section{Data 5}

A : Me da'da ae? (What are you cooking now?)

B : Me da'da banggai we palolano. O roti ae aicua a? (I am cooking the Moringa vegetable and eggplant. What kind of that bread?)

A : O roti kapute. (White Bread)

B : We incino we laloa? (Is there any filling inside?)

A : Umbe. Me da'da banggai we palolano maka da aomaomu. (Yes. Then, cooking the Moringa vegetable and eggplant now after that I will eat)

STRATEGY: KP (Casual)

\section{e. Hirarki Non Kerabat (+P +D -K)}

This is the interaction between two people which recognize and respect the social distance that places $A$ is super ordinate position and $B$ is subordinate position. 


\section{Data 6}

A : Naefie ne kan o laporan a da'kumpuluemo. Fo selesaiemomu laporanmiua. (Tomorrow, the report will be collected. You have to finish yours)

B : Umbe ibu. (Yes, Madam)

A : Pa'da aicu wa aneomu we ino'ida. Fe kahimba ao e. (After you finish it, give it to me. Be quickly)

B : Umbe ibu. (Yes, Madam)

STRATEGY : HIERARKI

\section{f. Hirarki Kerabat (+P -D +K)}

\section{Data 7}

This is the interaction between two people which have kinship relation. A is a wife and $B$ is a husband.

A : O Bapa, be ino'di doimu so ae oli kenta,. Minamo be kenta'a. (Dad, I want your money. I want to buy some fishes because there is no more)

$\mathrm{B}$ : Se ae hama angko. (how much must I give you?)

A : Na moono pa'a Bapa. Ulanomo no ali kenta'a. (One hundred. The fish is very expensive now)

STRATEGY: MIXED (HIERARCHY)

\section{Data 8}

This is the interaction is still in kinship relation. $A$ is a daughter and $B$ is a mother.

A : Aini kagomu ka oliaku we manggasa. Fo ohue seone sealoa. (This is your medicine. I bought it in Makassar. Take it one for a day)

$\mathrm{B}$ : Kagono ae aicua? (What medicine is that?)

A : Kagono vitamin. Komolimpua aicua Inae. Kohondoa seonu. (The medicine is vitamin. Don't forget to take it one for night)

STRATEGY: MIXED

Based on the data presentation of the dialogue transcription, it can be classified the politeness strategy on social interaction in Munanese Dialect Gu. The data were tabulated below:

Table 1. The Classification of Politeness Strategy on Social Interaction in Munanese Dialect Gu 


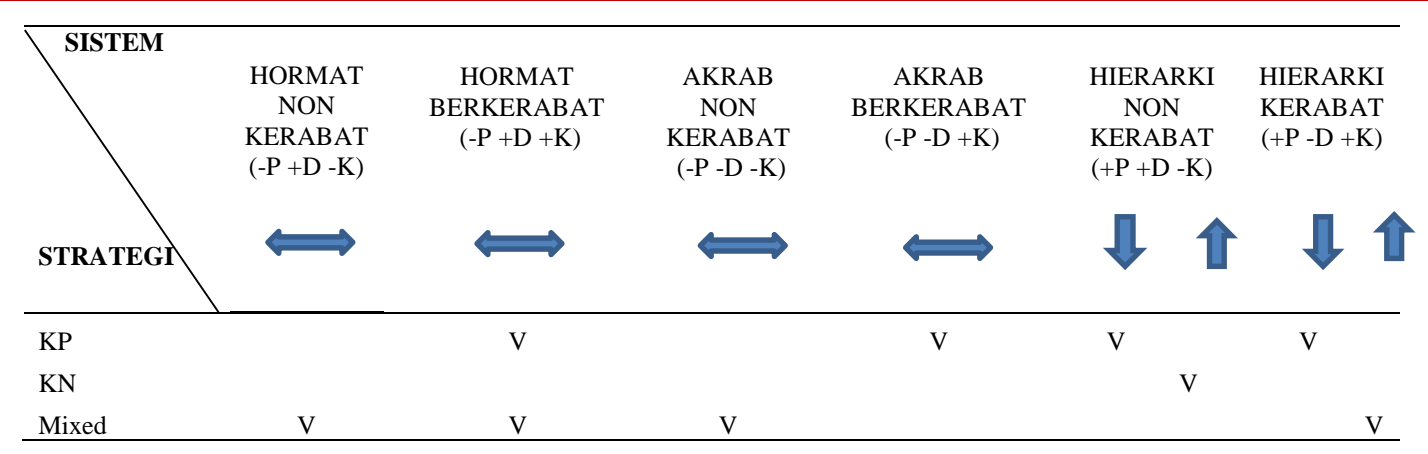

\section{Discussion}

Based on the table above, it showed that the data number (1) which is the system is Hormat Non Kerabat used Mixed strategy between two people who do not know each other. Sometimes they used nto as from persona nomina intao'di (You: polite way) and also use direct speech.

In data number (2) which is the system is Hormat Berkerabat shows that the strategy used by the speaker and the hearer are mixed. The use of nto appears because there is the different of the age between speaker and hearer. Moreover, they also use language of intimacy which shows the casual way. This strategy is also occurred in the system of Akrab Non Kerabat in the data number (4).

On the other hand, the data number (3) shows another strategy even it still in the same system of Hormat Berkerabat. The strategy used in the conversation is positive politeness $(K P)$. It can be seen when that the speech is more direct, lag of social attributes, and casual honorific. Furthermore, in the system of Akrab Berkerabat also used positive politeness (KP) as proven in the data number (5) because there is no social attributes in the language they used.

The data number (6), (7) and (8) is in the asymmetry system. In the system, one places in a superodinate position and the other in a subordinate position. In Data number (6), the speaker as one who is superior used positive politeness $(K P)$ to the hearer. While the hearer who is as the imperior one use the negative politeness $(K N)$. In contrast, the data number (7) and (8) shows the superior use positive politeness (KP) and the imperior use the mixed strategy. It can be seen in the using of mu (You: impolite way) and the using of Bapa (Dad), Ina (Mom) as deferent honorific.

In Yassi (2012) the politeness strategies used by Makassarrese based on the six strategies are Hormat Non Kerabat; mixed, Hormat berkerabat; positive politeness (KP), Akrab Non Kerabat; negative politeness (KN), Akrab Berkerabat; hierarki, Hierarki Non Kerabat; mixed (hierarki), and Hierarki Kerabat; mixed.

If it compares the data to the Yassi's theory, there are some similarities and differences in the using of politeness strategy. In the system of Hormat Non Kerabat, Hormat berkerabat, Hierarki Non Kerabat, and Hierarki Kerabat both of them used the same strategies. However in the system of Akrab Non Kerabat, in Yassi's theory the strategy used negative politeness (KN), Akrab Berkerabat used hierarki, In Munanese Dialect Gu the system of Akrab Non Kerabat used mixed and Akrab Berkerabat used positive politeness (KP). It caused by some factors such as cultural differences and social status. 


\section{Conclusion}

After analyzing the data, the writer concluded Dialect $\mathrm{Gu}$ in Munanese used some strategy of politeness in their daily interaction. Under the framework of Brown and Levinson's politeness strategy theory and supported by Yassi's theory, this paper explored the differences in the application of politeness strategies in Munanese Dialect Gu.

The result of the study showed the pattern politeness strategies used are; Hormat Non Kerabat; mixed, Hormat berkerabat; mixed and positive politeness (KP), Akrab Non Kerabat; mixed, Akrab Berkerabat; positive politeness (KP), Hierarki Non Kerabat; mixed (hierarchy), and Hierarki Kerabat; mixed.

There are some similarities and differences of the strategies used by Munanese Dialect $\mathrm{Gu}$ and Makassarese based on Yassi's theory. In the system of Hormat Non Kerabat, Hormat berkerabat, Hierarki Non Kerabat, and Hierarki Kerabat both of them used the same strategies. However in the system of Akrab Non Kerabat, in Yassi's theory the strategy used negative politeness $(K N)$, Akrab Berkerabat used hierarki, In Munanese Dialect Gu the system of Akrab Non Kerabat used mixed and Akrab Berkerabat used positive politeness $(K P)$. The differences of the strategies maybe caused by several possible reasons including cultural differences, different age and social status when the people interact each other.

\section{Acknowledgement}

This article is resolved with the help of various parties. Therefore, through this paper, the writer would like to thank Prof. Dr. Abd. Hakim Yassi, Dipl. TESL., M.A. who has given the encouragement, motivation, support and helpful comment. Furthermore, thanks to the Head of English Language study program, Dr. Fathu Rahman, M. Hum for the support to complete of this paper.

\section{References}

Brown and Levinson. (1987). Politeness : Some Universals in Language Usage. New York : Cambridge University Press

Mey, Jacob L. (2001). Pragmatics: An Introduction, $2^{\text {nd }}$ Edition. British Library: Blackwell Publisher

Scollon et all. (2012). Intercultural Communication. UK: Wiley-Blackwel

Yassi A.H. (2012). Negating and Affirming a proposition in Makassarese: Universality of Brown and Levinson's Politeness Theory in F.Rahman (ed) Kebahasaan, Sastra dan Pendidikan. International seminar Proceeding. FIB. Hasanuddin University. Makassar

Yassi A.H. (2017). Code Switching as a Communication Strategy. Yogyakarta: Trust Media.

Yule, George. (1996). Pragmatics. London: Oxford University Press 